Article

\title{
Impact and Control of Powdery Mildew on Irrigated Soybean Varieties Grown in Southeast Australia
}

\author{
Mathew W Dunn ${ }^{1, *}$ and Luke G Gaynor ${ }^{2,3}$ \\ 1 New South Wales Department of Primary Industries, Australian Cotton Research Institute, Narrabri, \\ NSW 2390, Australia \\ 2 Grains Research and Development Corporation, Wagga Wagga, NSW 2650, Australia; \\ Luke.Gaynor@grdc.com.au \\ 3 Formerly New South Wales Department of Primary Industries, Wagga Wagga Agricultural Institute, \\ Wagga Wagga, NSW 2650, Australia \\ * Correspondence: mathew.dunn@dpi.nsw.gov.au; Tel.: +61-26799-2436
}

Received: 5 March 2020; Accepted: 1 April 2020; Published: 3 April 2020

Abstract: Powdery mildew—caused by the fungus Erisyphe diffusa (syn. Microsphaera diffusa)—was first observed in commercial soybean crops in southern New South Wales (NSW), Australia, in 2011. Its detection raised concerns that soybean production might be constrained if the severity of the disease reached the levels observed in northern Australia. Field experiments were conducted over four consecutive seasons to examine the response of three soybean cultivars-Djakal, Snowy ${ }^{\mathrm{A}}$ and the breeding line N005A-80 - to two fungicides and two fungicide application regimes. The cultivar Djakal was identified as having a high level of resistance to powdery mildew. The severity of infection symptoms varied between seasons. The most severe symptoms were observed during the 2014-2015 season which resulted in the largest grain yield reduction of 20\% for the cultivar Snowy $^{\mathrm{A}}$. All fungicide treatments provided a significant reduction in the severity of symptoms, with the split application of tebuconazole and both the single and split applications of tebuconazole + prothioconazole providing the most effective control of the disease. Few other grain yield effects were found, even when strong disease control was achieved. This was a suspected result of the consistent late-in-the-season onset of the disease. Few differences were observed among the treatments in terms of lodging severity, date of physiological maturity, or grain oil and protein concentrations. It was concluded that both fungicides provided effective control of powdery mildew. However, when disease pressure is low, application might not be warranted in southern NSW.

Keywords: soybean; powdery mildew; fungicide

\section{Introduction}

Powdery mildew-caused by the fungus Erisyphe diffusa (syn. Microsphaera diffusa)-is an important disease of soybeans, particularly in the United States, Paraguay, Brazil and Bolivia. However, this disease has only recently been observed in Australia [1-6]. The fungus is an obligate parasite and is characterised by white-grey mycelia and conidia growth which can be observed on all above-ground plant parts [1,6]. During the early disease development stages, fine off-white or white fugal growth appears on the top surface of leaves [1]. As the disease develops, the bottom surface of leaves will sometimes turn red in colour, while the fungal growth on the top surface of leaves enlarges, potentially covering entire leaf surfaces [1]. Infection can significantly disrupt critical plant processes including photosynthesis and transpiration [7]. Yield losses resulting from powdery mildew infection as high as $50 \%-60 \%$ have been reported in many countries [3,5].

Powdery mildew was first observed as a minor outbreak in Australia during the 2010-2011 growing season [2,8]. A mild, wet 2012-2013 season resulted in widespread infection, which was 
particularly severe in the Darling Downs (southern Queensland), Liverpool Plains (northern NSW) and the Riverina (southern NSW) regions [9]. Since then, powdery mildew has been consistently observed in soybean crops every season throughout Australia's soybean-growing regions. Despite this, no Australian research to date has examined the effect of powdery mildew on grain yield, other agronomic properties or the effectiveness of possible control techniques.

Little is known about the survival mechanisms, host range or effectiveness of control techniques for this pathogen in Australian environments. However, research in other countries where powdery mildew is a common disease of soybean provides insight into its likely survival mechanisms and possible methods of control. It is likely that the disease survives between seasons on legume hosts, such as volunteer soybean, field pea and other broadleaf weeds within its host range, before re-infecting crops in the following season [10]. The application of fungicides and the selection of resistant cultivars have been identified as two effective, commonly used approaches of managing powdery mildew [6].

The fungicides, tebuconazole and prothioconazole, are used in North America, South America and Africa to control powdery mildew infection in soybean crops [6,11]. Prothioconazole is currently not registered for use in soybeans in Australia. However, a minor use permit issued by the Australian Pesticides and Veterinary Medicines Authority (APVMA) allows the use of tebuconazole in soybeans in Australia (PER82518, expiry 31 March 2022). Both fungicides are in the triazole group and act by inhibiting sterol biosynthesis [12]. This mode of action can cause a range of non-fungicidal effects, including the reduction in gibberellin biosynthesis and increased abscisic acid synthesis, potentially affecting soybean plant growth [12,13].

This study examines the effect of a range of fungicide treatments on three soybean cultivars in the presence of naturally occurring powdery mildew in soybeans in southern NSW.

\section{Materials and Methods}

\subsection{Field Site}

This study was conducted over four consecutive seasons (2013-2014, 2014-2015, 2015-2016 and 2016-2017) at 'Leeton Field Station' ( $34^{\circ} 28^{\prime}$ S, $146^{\circ} 25^{\prime}$ E) in southern NSW. Soil type at this location was a grey, self-mulching clay, described as a vertosol by Isbell [14] under the Australian Soil Classification. The field layout consisted of raised beds on $1.83 \mathrm{~m}$ centres with inter-bed furrows of $\sim 0.25 \mathrm{~m}$ in depth. Irrigation water was supplied from a head ditch through gravity fed siphons of $40 \mathrm{~mm}$ in diameter. Each irrigation lasted for $24 \mathrm{~h}$, with excess water draining away. Irrigations were scheduled based on crop growth stage and estimated crop water usage in order to avoid plant moisture stress.

Prior to each growing season, the fields were maintained as weed free using herbicides. Beds were cultivated and shaped prior to sowing to ensure flat uniform bed surfaces. The field site was pre-watered approximately 10 days before sowing to ensure adequate moisture for germination and establishment. Sowing was conducted within the optimum sowing window for the region; 4 December 2013, 11 December 2014, 2 December 2015 and 1 December 2016. A 3-point linkage single bed cone-seeder was used with a target plant density of 35 plants $/ \mathrm{m}^{2}$. Row spacing was $0.915 \mathrm{~m}$, with two plant rows per bed. A grain legume starter fertiliser $(\mathrm{N}=13.3, p=14.3, \mathrm{~S}=9, \mathrm{Zn}=0.81)$ was applied at $125 \mathrm{~kg} / \mathrm{ha}$, banded $5 \mathrm{~cm}$ to the side and $5 \mathrm{~cm}$ below each seed row. Inoculum (group H rhizobium, Bradyrhizobium japonicum) was applied directly behind the seeding boot as a peat slurry aqueous solution at $100 \mathrm{~L} / \mathrm{ha}$.

The field was maintained as weed free throughout the season using a combination of inter-row cultivation and hand weeding. Insecticides (deltamethrin and indoxacarb) were applied to control chewing and sucking pests as per commercial practice.

\subsection{Experimental Design}

Three indeterminate soybean cultivars were evaluated in this study. They included Djakal, a high yielding human consumption commercial cultivar that is currently the industry standard in southern 
NSW; Snowy A a culinary quality commercial cultivar; and the breeding line, N005A-80, a high yielding culinary quality cultivar currently in the pre-release stage [9].

The fungicide treatments consisted of tebuconazole at $430 \mathrm{~g} / \mathrm{L}$ and tebuconazole + prothioconazole each at $210 \mathrm{~g} / \mathrm{L}$, both as a single application (at growth stage R2) and as a split application (at growth stage R2 and two weeks later). Fungicides were applied with a shielded single bed sprayer at a water rate of $204 \mathrm{~L} /$ ha with Teejet 110025 AIXR nozzles. More details of the fungicide treatments and application regime are presented in Table 1.

The experiment design for all four seasons was the same. It consisted of a factorial arrangement with soybean cultivar and fungicide treatments as factors within a randomized complete block design, with soybean buffer plots surrounding each experiment. Plots were $10.5 \mathrm{~m}$ in length and $1.83 \mathrm{~m}$ (1 bed) in width.

Table 1. Fungicide treatments and application regimes for each season of field experiments.

\begin{tabular}{|c|c|c|c|c|c|}
\hline \multirow[b]{2}{*}{ Treatments } & \multirow[b]{2}{*}{$\begin{array}{c}\text { Application } \\
\text { Regime }\end{array}$} & \multicolumn{2}{|c|}{ At R2 Growth Stage } & \multicolumn{2}{|c|}{ Two Weeks after R2 } \\
\hline & & Rate (mL/ha) & Adjuvant $^{1}$ & Rate (mL/ha) & Adjuvant ${ }^{1}$ \\
\hline 2013-2014 & & & & & \\
\hline Untreated control & - & - & - & - & - \\
\hline Tebuconazole & Single ${ }^{2}$ & 150 & $1 \%$ & - & - \\
\hline Tebuconazole + prothioconazole & Single 2 & 400 & $1 \%$ & - & - \\
\hline $\begin{array}{l}\text { Tebuconazole + prothioconazole } \\
\text { 2014-2015, 2015-2016 and } \\
\text { 2016-2017 }\end{array}$ & Split ${ }^{3}$ & 200 & $1 \%$ & 200 & $1 \%$ \\
\hline Untreated control & - & - & - & - & - \\
\hline Tebuconazole & Single ${ }^{2}$ & 240 & $1 \%$ & - & - \\
\hline Tebuconazole & Split ${ }^{3}$ & 200 & $1 \%$ & 200 & $1 \%$ \\
\hline Tebuconazole + prothioconazole & Single ${ }^{2}$ & 400 & $1 \%$ & - & - \\
\hline Tebuconazole + prothioconazole & Split $^{3}$ & 200 & $1 \%$ & 200 & $1 \%$ \\
\hline
\end{tabular}

\footnotetext{
${ }^{1}$ A non-ionic surfactant was used in all fungicide applications; ${ }^{2}$ one fungicide application at R2 growth stage;
}

${ }^{3}$ one fungicide application at R2 growth stage and a second application two weeks later.

\subsection{Data Collection and Statistical Analysis}

Powdery mildew infection severity was determined at a plot level by the visual assessment of the percentage of leaves in the entire canopy with powdery mildew infection symptoms at the R7 growth stage. Lodging severity was determined by the assignment of visual lodging scores from 1 to 5 $(1=$ erect plants, $5=$ prostrate plants). Grain yield was determined by mechanically harvesting each plot using a field-plot harvester (Kingaroy Engineering Works, Kingaroy Queensland). Plot dimensions were measured to allow the exact harvest area of each plot to be calculated. Plots were harvested as soon as possible once maturity was reached (R9) to avoid seed loss from shattering [15]. Seed protein and oil concentration was determined using a Cropscan 2000B NIR Analyser (NIR Technologies Australia) and expressed as a percentage, standardised at $12 \%$ moisture. Days to physiological maturity (P95) was determined by visual observation (defined as when $95 \%$ of pods had lost chlorophyll). Plant growth stages were determined based on the stage of development descriptions established by Fehr et al. [15]. Average monthly maximum and minimum temperatures were obtained from a weather station operated by the Australian Government, Bureau of Meteorology, at nearby Yanco Agricultural Institute $\left(34.62^{\circ} \mathrm{S}, 146.43^{\circ} \mathrm{E}\right), 6 \mathrm{~km}$ east of the field site.

As the treatments were not identical across years, each year/experiment was analysed independently. Analysis of variance was conducted on grain yield and grain quality measurements using the ANOVA feature in GenStat (Version 18, VSN International Ltd., UK) to determine significant effects due to soybean cultivar, fungicide treatment and any treatment interactions. Due to the failure of the homogeneity of variance assumption for the powdery mildew infection symptom severity (\%) measurements, restricted maximum likelihood (REML) analyses were conducted on these 
measurements. The model fitted consisted of cultivar and fungicide as fixed and block as random variables. Fisher's least significant difference (1.s.d.) was used with a $p$ value of 0.05 for the separation of mean differences.

\section{Results}

\subsection{Temperature}

Weather conditions varied between seasons; 2013-2014 and 2014-2015 recorded average maximum temperatures close to the long-term average during March $\left(28.8^{\circ} \mathrm{C}\right)$ and April $\left(24.2^{\circ} \mathrm{C}\right)$, while the 2015-2016 and 2016-2017 seasons were characterised by above average maximum temperatures during the same period (31.4 and $26.9^{\circ} \mathrm{C}$ in $2015-2016$; 31.6 and $24.4^{\circ} \mathrm{C}$ in 2016-2017, respectively) (Figure 1).

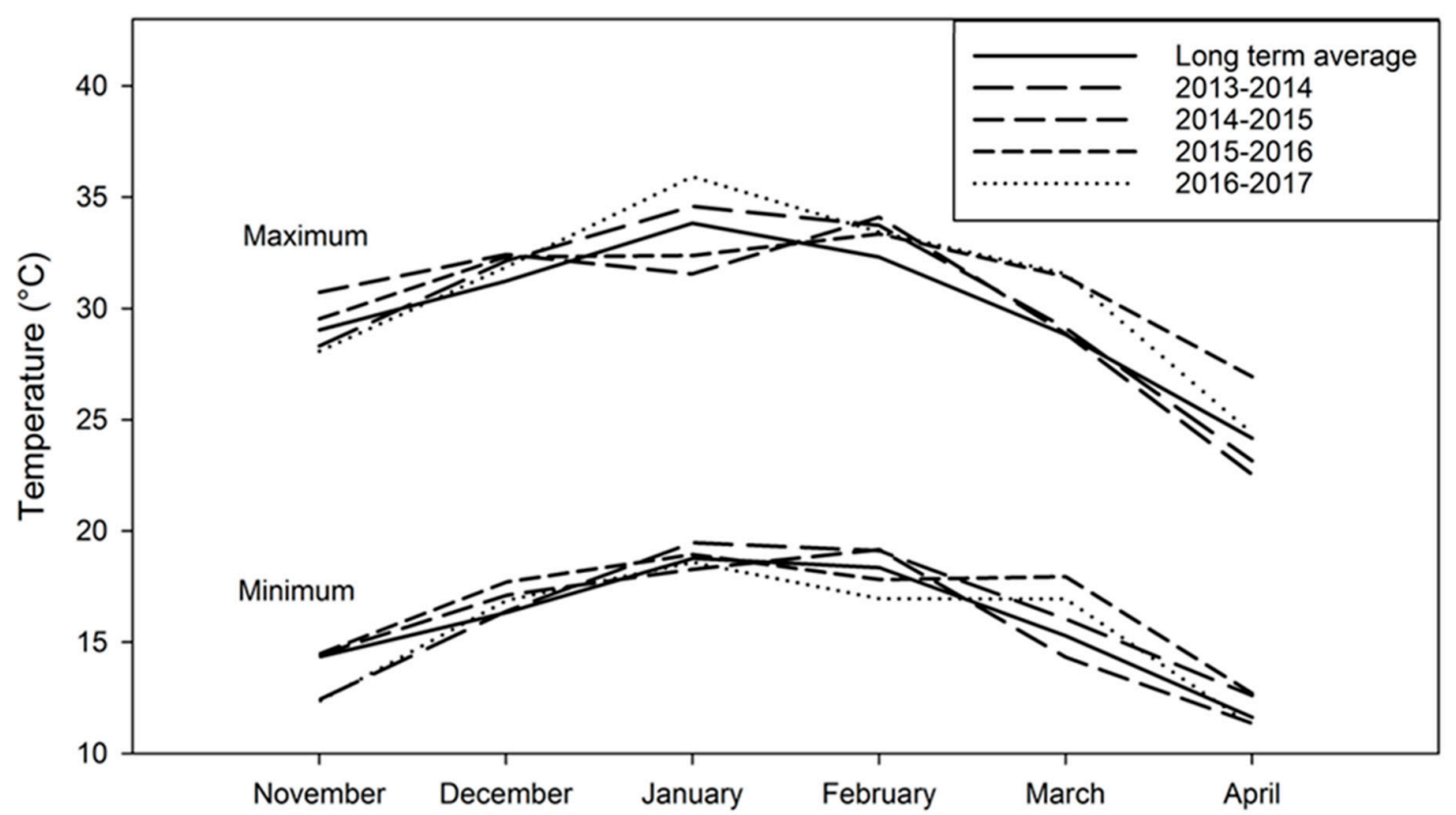

Figure 1. Average monthly minimum and maximum temperatures for each growing season and the long-term average [16] at Yanco Agricultural Institute $\left(34.62^{\circ} \mathrm{S}, 146.43^{\circ} \mathrm{E}\right), 6 \mathrm{~km}$ east of the field site. Long-term average 1999-2016.

\subsection{Powdery Mildew Infection}

In each season, powdery mildew was first observed in early March (growth stage R6) before reaching its maximum severity in early April (growth stage R7) when leaf drop began. Severity of powdery mildew infection symptoms varied significantly $(p=0.05)$ between cultivars, fungicide treatments and cultivar/fungicide treatment interactions in all four years (Table 2). No infection symptoms were observed for Djakal in the control or in any of the fungicide treatments in any of the seasons, supporting its known genetic resistance. In all four seasons, the severity of infection for both susceptible cultivars, Snowy ${ }^{\mathrm{A}}$ and N005A-80, was significantly higher in the control treatment than the four fungicide treatments. This result was expected given the common recommendation of these fungicides for powdery mildew control in other soybean-growing countries $[6,11]$. 
Table 2. Fungicide treatment effects on powdery mildew infection severity (\%) during growth stage R7 for three cultivars in four years of field experiments at Leeton Field Station, New South Wales.

\begin{tabular}{|c|c|c|c|c|c|c|c|c|c|c|c|c|}
\hline \multirow{4}{*}{ Treatments } & \multicolumn{4}{|c|}{ Djakal } & \multicolumn{4}{|c|}{ Snowy } & \multicolumn{4}{|c|}{ N005A-80 } \\
\hline & 2013 & 2014 & 2015 & 2016 & 2013 & 2014 & 2015 & 2016 & 2013 & 2014 & 2015 & 2016 \\
\hline & - & - & - & - & - & - & - & - & - & - & - & - \\
\hline & 2014 & 2015 & 2016 & 2017 & 2014 & 2015 & 2016 & 2017 & 2014 & 2015 & 2016 & 2017 \\
\hline Untreated control & 0 & 0 & 0 & 0 & 98 & 98 & 58 & 45 & 76 & 99 & 55 & 16 \\
\hline $\begin{array}{l}\text { Tebuconazole (single } \\
\text { application) }{ }^{1}\end{array}$ & 0 & 0 & 0 & 0 & 62 & 74 & 16 & 4 & 54 & 54 & 10 & 0 \\
\hline $\begin{array}{l}\text { Tebuconazole (split } \\
\text { application) }\end{array}$ & $-{ }^{2}$ & 0 & 0 & 0 & $-{ }^{2}$ & 6 & 1 & 1 & $-{ }^{2}$ & 30 & 1 & 1 \\
\hline $\begin{array}{c}\text { Tebuconazole }+ \\
\text { prothioconazole } \\
\text { (single application) }\end{array}$ & 0 & 0 & 0 & 0 & 15 & 0 & 0 & 0 & 6 & 5 & 3 & 1 \\
\hline $\begin{array}{c}\text { Tebuconazole }+ \\
\text { prothioconazole } \\
\text { (split application) }\end{array}$ & 0 & 0 & 0 & 0 & 1 & 28 & 0 & 0 & 0 & 34 & 0 & 0 \\
\hline 1.s.d. $(p=0.05)$ & n.s. & n.s. & n.s. & n.s. & 16 & 14 & 9 & 7 & 16 & 14 & 9 & 7 \\
\hline
\end{tabular}

The split application of tebuconazole and both single and split applications of tebuconazole + prothioconazole reduced powdery mildew infection symptom severity of both the susceptible cultivars (Snowy ${ }^{\mathrm{A}}$ and N005A-80) by an average of $91 \%, 95 \%$ and $92 \%$, respectively. In comparison the single application of tebuconazole only reduced powdery mildew infection symptom severity of Snowy ${ }^{\mathrm{A}}$ and N005A-80 by an average of $60 \%$ across the four seasons.

\subsection{Grain Yield and Other Agronomic Components}

Grain yield varied significantly $(p=0.05)$ between varieties in the 2014-2015, 2015-2016 and 2016-2017 seasons, with Djakal and N005A-80 significantly $(p=0.05)$ out yielding Snowy ${ }^{\mathrm{A}}$ in all three seasons. No significant $(p=0.05)$ interactions between varieties and fungicide treatment were found in any of four seasons.

Although measurable powdery mildew infection symptoms were detected in all four seasons and were significantly reduced by the fungicide treatments, few significant grain yield increases were found as a result of fungicide application (Table 3). No statistically significant $(p=0.05)$ grain yield variations between fungicide treatments were detected in the 2013-2014, 2015-2016 and 2016-2017 seasons. However, statistically significant $(p=0.05)$ grain yield increases did occur in the 2014-2015 season. In 2014-2015 season, the single and split application of tebuconazole + prothioconazole on the cultivar Snowy ${ }^{\mathrm{A}}$ resulted in an 18\% and 20\% grain yield increase, respectively, compared to the untreated control. These two grain yield increases were the only statistically significant grain yield variations from the untreated control.

A number of other agronomic components were also measured although few treatment responses were found. No significant effects were found for both plant lodging severity and seed protein concentration. A number of small differences in seed oil concentration and the number of days to physiological maturity were found but with no consistent or strong trends. 
Table 3. Fungicide treatment effects on soybean grain yield (t/ha) for three cultivars in four years of field experiments at Leeton Field Station, New South Wales.

\begin{tabular}{|c|c|c|c|c|c|c|c|c|c|c|c|c|}
\hline \multirow{4}{*}{ Treatments } & \multicolumn{4}{|c|}{ Djakal } & \multicolumn{4}{|c|}{ Snowy } & \multicolumn{4}{|c|}{ N005A-80 } \\
\hline & 2013 & 2014 & 2015 & 2016 & 2013 & 2014 & 2015 & 2016 & 2013 & 2014 & 2015 & 2016 \\
\hline & - & - & - & - & - & - & - & - & - & - & - & - \\
\hline & 2014 & 2015 & 2016 & 2017 & 2014 & 2015 & 2016 & 2017 & 2014 & 2015 & 2016 & 2017 \\
\hline Untreated control & 3.46 & 3.56 & 3.20 & 3.60 & 3.37 & 2.23 & 2.82 & 3.08 & 3.25 & 3.83 & 3.63 & 3.52 \\
\hline $\begin{array}{l}\text { Tebuconazole (single } \\
\text { application) }{ }^{1}\end{array}$ & 3.45 & 3.81 & 3.38 & 3.54 & 3.26 & 2.54 & 2.94 & 3.05 & 3.59 & 4.28 & 3.69 & 3.49 \\
\hline $\begin{array}{l}\text { Tebuconazole (split } \\
\text { application) }\end{array}$ & $-{ }^{2}$ & 3.92 & 3.22 & 3.42 & $-{ }^{2}$ & 2.69 & 3.22 & 2.91 & $-{ }^{2}$ & 4.20 & 3.77 & 3.73 \\
\hline $\begin{array}{c}\text { Tebuconazole }+ \\
\text { prothioconazole } \\
\text { (single application) }\end{array}$ & 3.54 & 3.33 & 3.39 & 3.59 & 3.40 & 3.73 & 3.06 & 3.05 & 3.25 & 4.29 & 3.61 & 3.73 \\
\hline $\begin{array}{c}\text { Tebuconazole }+ \\
\text { prothioconazole } \\
\text { (split application) }\end{array}$ & 3.13 & 3.55 & 3.30 & 3.77 & 3.70 & 2.77 & 2.96 & 3.34 & 3.55 & 4.05 & 3.56 & 3.75 \\
\hline l.s.d. $(p=0.05)$ & n.s. & n.s. & n.s. & n.s. & n.s. & 0.46 & n.s. & n.s. & n.s. & n.s. & n.s. & n.s. \\
\hline
\end{tabular}

\section{Discussion}

The late season onset of powdery mildew observed (early march, growth stage R6) is likely associated with the decrease in temperature that occurs at this time, with the long-term average maximum temperature at Leeton dropping from $32.4^{\circ} \mathrm{C}$ in February to $28.8^{\circ} \mathrm{C}$ in March (Figure 1). This is consistent with reports in the literature that the development of powdery mildew occurs rapidly at $18-24{ }^{\circ} \mathrm{C}$ but is restricted or inhibited at $30^{\circ} \mathrm{C}[17,18]$.

The severity of infection varied between seasons and was higher for the untreated susceptible cultivars, Snowy ${ }^{A}$ and N005A-80, in the 2013-2014 and 2014-2015 seasons than in the 2015-2016 and 2016-2017 seasons (Table 2). The higher temperatures experienced during March and April (particularly above $30^{\circ} \mathrm{C}$ ) in the 2015-2016 and 2016-2017 seasons were likely inhibitory to the development of powdery mildew and therefore contributed to lower overall severity in these seasons. Irrespective of the severity of infection, powdery mildew consistently developed late (R6 and R7 growth stages) in the growing season in all four seasons.

Studies of similar fungicide chemistry in other crop types have reported similar levels of fungal disease control as this study. Multiple applications of tebuconazole in peanuts decreased the incidence and defoliation severity of the fungal disease 'Southern stem rot' in peanuts [19]. Similarly, the combination of tebuconazole and prothioconazole was found to be more effective at controlling the fungal disease 'Leaf spot' in peanuts than tebuconazole alone [20]).

It is not widely appreciated that the fungicides examined in this study can cause a range of non-fungicidal effects, which potentially affect soybean plant growth and grain yield [12,13]. However, the grain yield of the resistant cultivar, Djakal, was unaffected by fungicide application, which indicates that yield effects on the susceptible varieties were attributed to the control of powdery mildew rather than any non-fungicidal effects.

Given the severity of symptoms observed in all four seasons, it was expected that greater reductions in grain yield would have occurred, although this expectation may have been misplaced. As powdery mildew is a highly visible disease with dense mycelium and conidia growth on leaf surfaces, there is a tendency to overestimate the damage it causes [1]. Yield losses resulting from powdery mildew are variable, with many studies reporting large yield losses, whereas others report minimal or no losses even in the presence of severe powdery mildew symptoms [1,3,5]. It also has been suggested that disease progress relative to growth stage may be a critical factor in yield loss, with recent research identifying that there is no strong relationship between grain yield and powdery mildew severity at late growth stages (R6 and R7) [3,21]. 
Although powdery mildew significantly reduces critical plant processes, including photosynthesis and transpiration [7], few statistically significant increases in grain yield were found even when a high level of powdery mildew control was achieved. It is suspected that the disease onset late in the season and likely overestimation of disease severity accounts for the absence of yield effects in these experiments.

\section{Conclusions}

Interest in powdery mildew and its effects on soybean production has been growing in Australia since its widespread outbreak in the 2010-2011 growing season in Australia's soybean-growing regions. This field study is the first of its kind to assess the impact of naturally occurring powdery mildew infection symptoms on soybean grain yields in southern NSW as well as the effectiveness of fungicides and fungicide application regimes. Both Snowy ${ }^{\mathrm{A}}$ and N005A-80 cultivars encountered significant powdery mildew infection symptoms in all four seasons, while Djakal displayed its strong resistance with no infection symptoms being recorded. Based on the visual presence of powdery mildew infection symptoms, all fungicide treatments tested in all seasons were effective at reducing infection symptom severity on susceptible cultivars over the untreated control. The single application of tebuconazole was found to be least effective, with the split application of tebuconazole and both the single and split application tebuconazole + prothioconazole providing the highest reduction in powdery mildew infection symptoms. While both Snowy ${ }^{\mathrm{A}}$ and N005A-80 cultivars encountered substantial infection symptoms in all seasons, significant grain yield reductions in the untreated control vs. fungicide treatments were only found for the cultivar Snowy ${ }^{\mathrm{A}}$ in the 2014-2015 season. It also is important to note that relying solely on a single fungicide mode of action for pathogen control increases the possibility of developing resistance and is therefore not recommended.

The application of fungicides for control of powdery mildew is not always warranted. The research findings presented here show that although effective, fungicide use in soybean in southern NSW should only be considered in seasons with high infection severity in highly susceptible cultivars.

Author Contributions: Conceptualization, L.G.G.; methodology, L.G.G.; validation, L.G.G.; formal analysis, M.W.D.; investigation, M.W.D. and L.G.G.; resources, M.W.D. and L.G.G.; data curation, M.W.D. and L.G.G.; writing-original draft preparation, M.W.D.; writing-review and editing, M.W.D. and L.G.G.; visualization, M.W.D. and L.G.G.; supervision, M.W.D. and L.G.G.; project administration, M.W.D. and L.G.G.; funding acquisition, L.G.G. All authors have read and agreed to the published version of the manuscript.

Funding: This research was supported with investment by the Grains Research and Development Corporation (GRDC) under the Southern NSW Soybean Agronomy Project (DAN00192).

Acknowledgments: The author would like to acknowledge the technical support of Alan Boulton, John Dando, Paul Morris and Gabby Napier.

Conflicts of Interest: The authors declare that there are no conflicts of interest.

\section{References}

1. Dunleavy, J. Soybean seed yield losses caused by powdery mildew. Crop Sci. 1978, 18, 337-339. [CrossRef]

2. McTaggart, A.R.; Ryley, M.J.; Shivas, R.G. First report of the powdery mildew Erysiphe diffusa on soybean in Australia. Australas. Plant Dis. Notes 2012, 7, 127-129. [CrossRef]

3. Phillips, D. Stability of Microsphaera diffusa and the effect of powdery mildew on yield of soybean. Plant Dis. 1984, 68, 953-956. [CrossRef]

4. Ryley, M. Mildew Diseases of Soybean. 2015. Available online: http://www.australianoilseeds.com/_data/ assets/pdf_file/0018/10368/Mildews_of_soybean_Feb_2015.pdf (accessed on 27 July 2016).

5. Wrather, J.A.; Anderson, T.R.; Arsyad, D.M.; Tan, Y.; Ploper, L.D.; Porta-Puglia, A.; Ram, H.H.; Yorinori, J.T. Soybean disease loss estimates for the top ten soybean-producing counries in 1998. Can. J. Plant Pathol. 2001, 23, 115-121. [CrossRef]

6. Yorinori, M.; Klingelfuss, L.; Paccola-Meirelles, L.; Yorinori, J. Effect of time of spraying of fungicide and foliar nutrient on soybean powdery mildew. J. Phytopathol. 2004, 152, 129-132. [CrossRef] 
7. Mignucci, J.S.; Lim, S. Powdery mildew development on soybeans with adult-plant resistance. Phytopathology 1980, 70, 919-921. [CrossRef]

8. Gaynor, L.; O'Keeffe, K.; Lattimore, M. Southern Soybeans Shine in a Wet Year. 2012. Available online: http://irec.org.au/farmer_f/pdf_187/Soybean-success-in-southern-regions.pdf (accessed on 27 July 2016).

9. Moore, N.; Serafin, L.; Jenkins, L. Summer Crop Production Guide. 2014. Available online: http://www.dpi. nsw.gov.au/_data/assets/pdf_file/0005/303485/Summer-crop-production-guide-2014.pdf (accessed on 27 July 2016).

10. Rico, M.C. Interactions of Microsphaera diffusa with soybeans and other legumes. Phytopathology 1978, 68, 169-173.

11. Mueller, J. Soybean Disease Control. In South Carolina Pest Management Handbook for Field Crops; Marshall, M., Ed.; Clemson Cooperative Extension: Clemson, SC, USA, 2015; pp. 256-260.

12. Fletcher, R.A. Plant growth regulating properties of sterol-inhibiting fungicides. In Hormonal Regulation of Plant Growth and Development; Springer: Dordrecht, The Netherlands, 1987; pp. 103-113.

13. Rademacher, W. Growth retardants: Effects on gibberellin biosynthesis and other metabolic pathways. Annu. Rev. Plant Biol. 2000, 51, 501-531. [CrossRef] [PubMed]

14. Isbell, R. The Australian Soil Classification; CSIRO publishing: Collingwood, VIC, Australia, 1996.

15. Fehr, W.R.; Caviness, C.E.; Burmood, D.T.; Pennington, J.S. Stage of Development Descriptions for Soybeans, Glycine max (L.) Merrill1. Crop Sci. 1971, 11, 929-931. [CrossRef]

16. Bureau of Meteorology, AG, Climate Data Online. Australian Government, Bureau of Meteorology. Available online: www.bom.gov.au (accessed on 27 July 2016).

17. Mignucci, J.S.; Boyer, J.S. Inhibition of photosynthesis and transpiration in soybean infected by Microsphaera diffusa. Phytopathology 1979, 69, 227-230. [CrossRef]

18. Yulia, E.; Widiantini, F.; Karuniawan, A.; Comoc, R. Resistance Potential to Powdery Mildew (Microsphaera diffusa Cooke and Peck) of Several Yellow and Black Soybean (Glycine max (L.) Merr) Genotypes. KnE Life Sci. 2017, 9, 270-278. [CrossRef]

19. Bowen, K.; Hagan, A.; Weeks, J. Number of tebuconazole applications for maximizing disease control and yield of peanut in growers' fields in Alabama. Plant Dis. 1997, 81, 927-931. [CrossRef]

20. Culbreath, A.; Kemerait, R., Jr.; Brenneman, T. Management of leaf spot diseases of peanut with prothioconazole applied alone or in combination with tebuconazole or trifloxystrobin. Peanut Sci. 2008, 35, 149-158. [CrossRef]

21. Carmona, M.; Sautua, F.; Perelman, S.; Gally, M.; Reis, E.M. Development and validation of a fungicide scoring system for management of late season soybean diseases in Argentina. Crop Prot. 2015, 70, 83-91. [CrossRef]

(C) 2020 by the authors. Licensee MDPI, Basel, Switzerland. This article is an open access article distributed under the terms and conditions of the Creative Commons Attribution (CC BY) license (http://creativecommons.org/licenses/by/4.0/). 